1. Department of Physiology, Al Tibri Medical College, Karachi 2. Department of Pathology, Al Tibri Medical College, Karach 3. Department of Physiology, Al Tibri Medical College, Karachi 4. Department of Pathology, Al Tibri Medical College, Karachi 5. Department of Physiology, Al Tibri Medical College, Karachi 6. Department of Physiology, Isra University Hyderabad

7. Department of Pathology, Isra University Hyderabad

8. Department of Anatomy, Al Tibri Medical College, Karach

Correspondence Address:

Dr. Amin Fahim, M.Phil

Assistant Professor

Deptt: of Pathology

Al Tibri Medical College

Old Thana, Gadap Town

Malir, Karachi

draminfahim@gmail.com

Article received on:

21/06/2014

Accepted for Publication:

$15 / 07 / 2014$

Received after proof reading:

$16 / 08 / 2014$

\section{EFFECTS OF CINNAMON EXTRACT IN DIABETIC RAT MODELS IN COMPARISON WITH ORAL HYPOGLYCEMIC DRUGS}

\author{
Dr. Muhammad Sajid Khan', Dr. Aneela Qureshi' ${ }^{2}$ Dr. Shuja Anwar Kazi ${ }^{3}$, Dr. Amin Fahim ${ }^{4}$, \\ Dr. Husan Bano ${ }^{5}$, Dr. Navaid Kazi ${ }^{6}$, Dr. Asghar Khan ${ }^{7}$, Dr. Mazhar ul Haque ${ }^{8}$
}

\begin{abstract}
Objective: To evaluate the anti diabetic effect of cinnamon extract in alloxan induced diabetic animal model (albino rats) in comparison with oral hypoglycemic drugs. Study Design: An Experimental study. Place of Study: Al Tibri Medical College, Isra University, Karachi Campus. Duration of Study: December 2012 to December 2013. Materials and Methods: Total 60 Albino rats of both genders were divided into 6 groups consisting of 10 rats in each group. Each group of animals was further divided into two sub groups containing 5 rats in each group Results: The results obtained from the data indicated that there is significant reduction in blood glucose level rats treated with low dose of cinnamon extract. The animals of low dose cinnamon extract $(200 \mathrm{mg} / \mathrm{kg}$. bw) when compared with other groups; there is a reduction in the blood glucose level in alloxan induced diabetic rats. Also tolbutamide and acarbose treated groups showed better antidiabetic effects as compared with cinnamon extract treated groups ( $p$ value $<0.007$ and $p$ value $<0.012$ respectively), but cinnamon extract treated group showed synergetic effects when it was given in combination with tolbutamide or acarbose having significant $p$ value $<0.001$ and $p$ value $<0.011$ respectively. Conclusions: Tolbutamide and Acarbose showed better anti diabetic effect in comparison with cinnamon extract treated groups when used individually. This effect was enhanced when cinnamon was used in combination with either tolbutamide or acarbose.
\end{abstract}

Key words: $\quad$ Cinnamon extract, Serum glucose, Diabetes.

Article Citation: Khan MS, Qureshi A, Kazi SA, Fahim A, Bano H, Kazi N, Khan A, Mazhar ul Haque. Effects of cinnamon extract in diabetic rat models in comparison with oral hypoglycemic drugs. Professional Med J 2014;21 (4): 717-722.

\section{INTRODUCTION}

According to WHO, the diabetes mellitus is categorized clinically and etiologically into two major types as type $1 \mathrm{DM}$ or insulin dependent diabetes mellitus (IDDM) and type II DM or non insulin dependent diabetes mellitus (NIDDM), ${ }^{1}$. Type I diabetes mellitus is also called as juvenile diabetes that usually occurs below the age of 40 years or in childhood. This is due to the complete or partial degeneration of beta cells of pancreas thus causing the deficiency of insulin ${ }^{2}$. On the other hand, type II diabetes mellitus that occur after the age of 40 years is usually non insulin dependent type of diabetes and is caused either by deficient secretion of insulin or due to the defect of insulin receptors. This type of disease is mild than juvenile type and can easily be controlled through diet and oral hypoglycemic drugs ${ }^{3,4}$.

Experimental induction of diabetes mellitus in various species of animal can be achieved with chemicals such as uric acid, dehydro ascorbic acid, magnesium and quinolone. However, the most frequently chemical method used in experimental work for the induction of diabetes in animal is through the administration of either alloxan or streptozotosin ${ }^{5,6}$.

First generation potassium channel blocker Tolbutamide under the brand name Orinase is used in the management of type II diabetes if diet is not impressive. Tolbutamide act by stimulating the secretion of pancreas. Generally it has a short duration of action due to its rapid metabolism. 
When given through oral route, it is rapidly absorbed from gastrointestinal tract. Absorption and glucose lowering and insulin releasing effect are not altered if the drug is taken with food. On the other hand Acarbose (glucobay) is an alpha glucosidase inhibitor can be used for the treatment of non insulin dependent (NIDDM) diabetes and insulin dependent (IDDM). The mechanism of action of acarbose is to inhibit the intestinal enzymes (alpha glucosidase) used in the degradation of disaccharides, oligosaccharides and polysaccharides. Acarbose (glucobay) also lowers abnormally high concentration of glycosylated hemoglobin, but in clinical practice have produced side effects ${ }^{7}$.

Thus there is increasing demand of herbal and natural products having anti diabetic activity with fewer side effects ${ }^{8}$. Marles and Farnsworth ${ }^{9}$ reported a scientific investigation of traditional herbal remedies for diabetes that may provide valuable leads for the development of alternative drugs and therapeutic strategies. Very little research work has been done to evaluate the comparative effect of ethanol based cinnamon extract with hypoglycemic drugs. Therefore, present study was carried out to evaluate the anti diabetic effect of ethanol based Cinnamon bark extract in allaxon induced diabetic rats in comparison with two oral hypoglycemic drugs tolbutamide and acarbose (glucobay).

\section{MATERIALS AND METHODS}

This is an experimental study conducted in the Department of Physiology Al Tibri Medical College and Hospital, Karachi from December 2012 to December 2013. Total 60 Albino rats of either gender were divided into 6 groups consisting of 10 rats in each group. Each group of animals was further divided into two sub groups containing 5 rats in each group. The distribution is as under:

\subsubsection{Group A $(n=10)$}

Further sub divided into two groups:

- Group A1 Simple control $(n=5)$---------Treated with normal saline only

- $\quad$ Group A2 Diabetic Control $(n=5)$---------Treated with Alloxan only

\subsubsection{Group B ( $\mathrm{n}=10)$}

Cinnamon extract treated group, further sub divided into:

- Group B1 $(n=5)$ - Treated with low dose extract

- Group B2(n=5)-Treated with high dose extract

\subsubsection{Group C ( $\mathrm{n}=10)$}

Tolbutamide treated group, further sub divided into:

- Group C1 $(n=5)$ - Low dose of tolbutamide

- Group C2 ( $n=5)$ - High dose of tolbutamide

\subsubsection{Group D ( $n=10)$}

Acarbose treated group

- Group D1 ( $n=5)$ - Low dose of acarbose

- Group D2 ( $(n=5)$ - High dose of acarbose

\subsection{Combination of Low \& High Dose Of Extract \\ + Tolbutainde \& Acarbose: \\ 1.5.1 Group E $(n=10)$ \\ Low dose of combination (Ext + drug) \\ $E_{1}(n=5)=L_{\text {Ext }}+L_{\text {Drug1 }}$ (Tolbutanide) \\ $E_{2}(n=5)=L_{\text {Ext }}+L_{\text {Drug2 }}$ (Acarbose)}

\subsubsection{Group F ( $\mathrm{n}=10)$}

High dose of combination (Ext + drug)

$\mathrm{F}_{1}(\mathrm{n}=5)=\mathrm{H}_{\text {Ext }}+\mathrm{H}_{\text {Drug } 1}$ (Tolbutamide)

$F_{2}(n=5)=H_{E x t}+H_{\text {Drug2 }}$ (Acarbose)

All the data obtained after experimental work was analyzed statistically by SPSS version 21 , Chi square test and student $\mathrm{T}$ test was used to compare the findings between the affected and control group. Statistically $\mathrm{P}$ value $<0.05$ was considered significant.

\section{RESULTS}

The anti diabetic effects of cinnamon extract were observed and compared with the control animals and anti diabetic drugs groups.

\section{Comparison of Blood Glucose Level within Group A}

Mean blood glucose level of group A1 was 115 where as in group A2 it was 280 as shown in Table I. Group A2 showed significant rise in blood glucose level after alloxan treatment. 


\section{Comparison of Blood Glucose Level within Group B}

Mean blood glucose level of group B1 was 165 where as in Group B2 it was 185 as shown in Table II. Group B1 showed more decrease in blood glucose level as compared to Group B2.

\section{Comparison of Blood Glucose Level within Group C}

Mean blood glucose level of group C1 was 140 where as in group C2 it was 135 as shown in Table III. Group C2 showed more decrease in blood glucose level as compare to Group C1.

\section{Comparison of blood glucose level within group D}

Mean blood glucose level of group D1 was 145 where as in group D2 it was 140 as shown in Table IV. Group D2 showed more decrease in blood glucose level as compare to Group D1.
5. Comparison of blood glucose level within group E

Mean blood glucose level of group E1 was 140 where as in group E2 it was 145 as shown in Table V. Group E1 showed more decrease in blood glucose level as compare to Group E2.

\section{Comparison of blood glucose level within group F}

Mean blood glucose level of group F1 was 130 where as in group F2 it was 135 as shown in Table VI. Group F1 showed more decrease in blood glucose level as compare to Group F2.

\section{DISCUSSION}

A variety of herbs reported in the scientific literature have hypoglycemic property and are important in reduction of blood sugar level, so these herbs are widely used in the management of diabetes $^{10,11}$. Despite of having ability in the control of diabetes therapeutically by using synthetic

\begin{tabular}{|l|c|c|c|c|c|c|c|}
\hline \multicolumn{7}{|c|}{} & \multicolumn{5}{c|}{ Blood glucose level (mg/dL) } \\
\hline \multicolumn{1}{|c|}{ Group } & Initial & $\mathbf{1}^{\text {st }}$ Day & $\mathbf{7}^{\text {th }}$ Day & $\mathbf{1 4}^{\text {th }}$ Day & $\mathbf{2 1}^{\text {st }}$ Day & $\mathbf{3 0}^{\text {th }}$ Day \\
\hline Normal Saline & $98 \pm 23.03$ & $102 \pm 26.27$ & $109 \pm 20.16$ & $115 \pm 19.40$ & $112 \pm 23.03$ & $115 \pm 27.30$ \\
\hline Alloxan & $114 \pm 23.03$ & $270 \pm 26.27$ & $280 \pm 20.16$ & $285 \pm 19.40$ & $290 \pm 23.03$ & $280 \pm 27.30$ \\
\hline & \multicolumn{3}{|c|}{ Table-I. Mean blood glucose level of group A1 and A2 } \\
\hline
\end{tabular}

\begin{tabular}{|l|c|c|c|c|c|c|}
\hline \multicolumn{1}{|c|}{ Blood glucose level (mg/dL) } \\
\hline \multicolumn{1}{|c|}{ Group } & Initial & $\mathbf{1}^{\text {st }}$ Day & $\mathbf{7}^{\text {th }}$ Day & $\mathbf{1 4}^{\text {th }}$ Day & $\mathbf{2 1}^{\text {st }}$ Day & $\mathbf{3 0}^{\text {th }}$ Day \\
\hline $\begin{array}{l}\text { Cinnamon extract } \\
\text { 200mg/kg }\end{array}$ & $110 \pm 23.03$ & $250 \pm 26.27$ & $200 \pm 20.16$ & $180 \pm 19.40$ & $170 \pm 23.03$ & $165 \pm 27.30$ \\
\hline $\begin{array}{l}\text { Cinnamon extract } \\
600 \mathrm{mg} / \mathrm{kg}\end{array}$ & $115 \pm 23.03$ & $265 \pm 26.27$ & $220 \pm 22.31$ & $210 \pm 25.45$ & $200 \pm 27.67$ & $185 \pm 20.44$ \\
\hline & Table-ll. Mean of blood glucose level of group B1 and B2 \\
\hline
\end{tabular}

\begin{tabular}{|l|c|c|c|c|c|c|}
\hline \multicolumn{1}{|c|}{} & \multicolumn{4}{|c|}{ Blood glucose level (mg/dL) } \\
\hline \multicolumn{1}{|c|}{ Group } & Initial & $1^{\text {st }}$ Day & $\mathbf{7}^{\text {th }}$ Day & $\mathbf{1 4}^{\text {th }}$ Day & $\mathbf{2 1}^{\text {st }}$ Day & $\mathbf{3 0}^{\text {th }}$ Day \\
\hline $\begin{array}{l}\text { Tolbutamide } \\
20 \mathrm{mg} / \mathrm{kg}\end{array}$ & $118 \pm 19.15$ & $270 \pm 16.35$ & $180 \pm 20.69$ & $160 \pm 24.64$ & $145 \pm 24.66$ & $140 \pm 19.09$ \\
\hline $\begin{array}{l}\text { Tolbutamide } \\
\mathbf{4 0} \mathrm{mg} / \mathrm{kg}\end{array}$ & $109 \pm 19.15$ & $250 \pm 16.35$ & $175 \pm 23.56$ & $155 \pm 26.36$ & $140 \pm 22.36$ & $135 \pm 21.10$ \\
\hline & & & & \\
\hline
\end{tabular}




\begin{tabular}{|c|c|c|c|c|c|c|}
\hline \multicolumn{7}{|c|}{ Blood glucose level (mg/dL) } \\
\hline Group & Initial & $1^{\text {st }}$ Day & $7^{\text {th }}$ Day & $14^{\text {th }}$ Day & $21^{\text {st }}$ Day & $30^{\text {th }}$ Day \\
\hline $\begin{array}{l}\text { Acarbose } 30 \\
\mathrm{mg} / \mathrm{kg}\end{array}$ & $110 \pm 24.26$ & $270 \pm 18.43$ & $180 \pm 20.58$ & $170 \pm 20.85$ & $155 \pm 21.40$ & $145 \pm 25.61$ \\
\hline $\begin{array}{l}\text { Acarbose } 60 \\
\mathrm{mg} / \mathrm{kg}\end{array}$ & $113 \pm 24.26$ & $268 \pm 18.43$ & $175 \pm 20.58$ & $168 \pm 20.85$ & $150 \pm 21.40$ & $140 \pm 25.61$ \\
\hline
\end{tabular}

Table-IV. Mean of blood glucose level of group D1 and D2

\begin{tabular}{|c|c|c|c|c|c|c|}
\hline \multicolumn{7}{|c|}{ Blood glucose level (mg/dL) } \\
\hline Group & Initial & $1^{\text {st }}$ Day & $7^{\text {th }}$ Day & $14^{\text {th }}$ Day & $21^{\text {st }}$ Day & $30^{\text {th }}$ Day \\
\hline $\begin{array}{l}\text { Cinnamon extract } \\
200 \mathrm{mg} / \mathrm{kg}+ \\
\text { Tolbutamide } 20 \mathrm{mg} / \mathrm{kg}\end{array}$ & $108 \pm 20.11$ & $250 \pm 21.09$ & $160 \pm 26.75$ & $155 \pm 22.26$ & $150 \pm 20.24$ & $140 \pm 19.24$ \\
\hline $\begin{array}{l}\text { Cinnamon extract } \\
200 \mathrm{mg} / \mathrm{kg}+ \\
\text { Acarbose } 30 \mathrm{mg} / \mathrm{kg}\end{array}$ & $112 \pm 20.31$ & $150 \pm 20.11$ & $250 \pm 21.09$ & $165 \pm 24.47$ & $160 \pm 25.15$ & $145 \pm 22.32$ \\
\hline
\end{tabular}

Table-V. Mean of blood glucose level of group E1 and E2

\begin{tabular}{|c|c|c|c|c|c|c|}
\hline \multicolumn{7}{|c|}{ Blood glucose level (mg/dL) } \\
\hline Group & Initial & $1^{\text {st }}$ Day & $7^{\text {th }}$ Day & $14^{\text {th }}$ Day & $21^{\text {st }}$ Day & $30^{\text {th }}$ Day \\
\hline $\begin{array}{l}\text { Cinnamon extract } \\
600 \mathrm{mg} / \mathrm{kg}+ \\
\text { Tolbutamide } 40 \mathrm{mg} / \mathrm{kg}\end{array}$ & $98 \pm 25.23$ & $250 \pm 20.31$ & $145 \pm 19.63$ & $138 \pm 21.24$ & $135 \pm 22.14$ & $130 \pm 20.18$ \\
\hline $\begin{array}{l}\text { Cinnamon extract } \\
600 \mathrm{mg} / \mathrm{kg}+ \\
\text { Acarbose } 60 \mathrm{mg} / \mathrm{kg}\end{array}$ & $100 \pm 25.23$ & $250 \pm 20.31$ & $150 \pm 18.96$ & $145 \pm 13.21$ & $140 \pm 17.12$ & $135 \pm 21.18$ \\
\hline
\end{tabular}

Table-VI. Mean of blood glucose level of group F1 and F2

drugs, many traditionally based plant materials are used as medicine in the control of diabetes ${ }^{12}$. Many pharmaceutical companies preparing some modern medicine are of natural plant origin. Cinnamon is amongst the most important and frequently used herbal drugs, commonly known as ADalchini@ used as spice and also involved in the treatment of various diseases such as gastric ulcers, diabetes and other inflammatory disorders. The present study has evaluated the anti diabetic effect of Cinnamon bark extract in alloxan induced diabetic rats and compared it with the oral hypoglycemic drugs i.e: tolbutamide and acarbose. To induced diabetes in rats $150 \mathrm{mg} / \mathrm{kg}$ body weight of alloxan monohydrate was injected intraperitoneally. Our study is also agreed with the studies of other researchers who also used alloxan monohydrate by giving a dose of $150 \mathrm{mg} / \mathrm{kg}$.bw to induce diabetes in rats ${ }^{14,15,16}$. The data regarding blood glucose obtained by the present study showed that alloxan induced diabetic rats produced significant increase in blood glucose level as shown in Table-l. This finding by the present study is almost in accordance with the studies of others ${ }^{17,18,19,20}$ who also reported a significant increase in blood glucose level in alloxan induced diabetic rats. The present study also assessed the anti diabetic effect of Cinnamon extract with low dose (200mg/kg body weight) and high dose $(600 \mathrm{mg} / \mathrm{kg}$ body weight) to diabetic rats. When cinnamon extract was administered to rats with low dose orally by feeding tube, 
significant reduction in blood glucose level was seen (Table-II).

The hypoglycemic drugs such as tolbutamide and acarbose on the other hand showed better anti diabetic effect as compared to cinnamon extract treated group ( $P$-value $<0.007$ and $P$ value $<0.012$ ) respectively, but cinnamon extract showed synergetic effect when it was given in combination with hypoglycemic drugs and showed significant $P$ value $<0.001$ and $P$ value $<0.0111$ respectively. Similarly when high dose $600 \mathrm{mg} / \mathrm{kg}$ of cinnamon extract was given to diabetic rats a comparatively less effect was noticed. The same findings were also reported in other studies ${ }^{21,22,23}$. It has also been claimed by many authors that the reduction in blood glucose level may be due to the active anti hypoglycemic agents present in extract as reported in literature ${ }^{24}$.

\section{CONCLUSIONS}

Tolbutamide and Acarbose groups showed better anti diabetic effect in comparison with cinnamon extract treated groups when used separately. This effect was enhanced when cinnamon was used in combination with either tolbutamide or a carbose.

\section{Copyright@ 26 June 2014.}

\section{REFERENCES}

1. Kazuya T, Matsuda A. Classification of diabetes on the basis of etiologies versus degree of insulin deficiency. Diabetes Care 1997; 20: 219B20.

2. Gillespie KM. Type 1 diabetes: pathogenesis and prevention. C and Med Assoc J 2006; 175 :165 170.

3. Rother $\mathrm{KI}$. Diabetes treatmentCbridging the divide. New Eng J Med 2007; 356: No.1499B1501.

4. Sunita S. The Genetics of Type 2 DiabetesMellitus: A Review Journal of Scientific Research Banaras Hindu University, Varanasi 2011; 55: 3548 .

5. Rees DA, Alcolado JC. Animal models of diabetes mellitus. Diabet Med 2005; 22: 359370.

6. Urban VS, Kiss J, Kovacs J, Gocza EV, Monotori E, Uher F. Mesenchymal stem cells cooperate with bone marrow cells in therapy of diabetes. Stem cell 2008; 26: 244253.
Qian Z, Xinhua X, Ming I, Wenhui I, Et al. Acarbose reduces blood glucose by activating $\mathrm{miR} 10 \mathrm{a} 5 \mathrm{P}$ and miR 664 in diabetic rats. 2013; 8,11 e79697.

8. Vetrichelvan T, Jagadeesan M. Antidiabetic activity of alcoholic extract of Aerva lanata (L.) Juss. ex Schultes in rats. J Ethnopharma 2002; 80: 103107.

9. Marles RJ, Fransworth NR. Antidiabetic plants and their active Constituents. Phytomedicine 1995; 2:137-189.

10. Karashima T, Schally AV. Superactive somatostatin analog decrease plasma glucose and glucagon levels in diabetic rats. Peptides 1988; 9(3) :561B5.

11. Angelova N, Kong HW, Heijden R, Yang SY, Choi YH, Kim. Recent methodology in the phytochemical analysis of gincing. Phytochem Anal 2008; $19: 2$ 16.

12. Genet S, Kale RK, Baquer NZ. Alterations in antioxidant enzymes and oxidative damage in experimental diabetic rat tissues: Effect of vanadate and fenugreek Trigonella faenum graceum. J Mol Cell Biochem 2002; $236: 712$.

13. Shera AS, Jawad F, Maqsood A. Prevalence of diabetes in Pakistan. Diabetes Res Clin Pract 2004; $76: 219222$

14. Etuk EU, Muhammed BJ. Evidence based analysis of chemical method of induction of diabetes mellitus in experimental rats. Int $\mathrm{J}$ Res.Pharm Sci 2010; $1: 139142$.

15. Wasfi H, Rafi D, Mohammed AU. Comparision of effect of various cinnamon plants extract with metformin in blood glucose level of alloxan induced diabetic laboratory rats. Kufa J Med Sci 2011;2: 28 .

16. Akiniola O, Gabriel M, Suleiman AA, Olorunsogbon F. Treatment of alloxan induced diabetic rats with metformin or glitazones is associated with amelioration of hyperglycemia and neuroprotection. The Open Diabetes Journal 2012; $5: 812$.

17. Ji SU, Jung K, Bong J, Chang W, Sei CK. Hypoglycemic and antihyperlipidemic effect of four Korean medicinal plants in alloxan induced diabetic rats. Am J Biochem Biotech 2006; 2 : 154 160.

18. Ene AC, Nwandwo EA, Samdi IM. Alloxan induced diabetes in rats and the effect of black caraway (carum carvi I.) oil on their total body weight. Res J Medicine Med Sci 2007; 2: 4852. 
19. Dharmeshkumar DP, Patel NM, Savadi RV, Akki KS, Mruthurijaya K. Alleviation of alloxan induced diabetes and its complication in rats by actinodaphne hookeri leaf extract. Bangladesh $\mathrm{J}$ Pharmacol 2008; 3 : 102106.

20. Luiz C, Nunes P, De Morais C, Cristiane M, Milton C. Effect of alloxan induced diabetes mellitus and ethanol on pregnancy outcome in mice. J Bras Pathol Med Lab 2009; 45: 471480.

21. Mahmood S, Aisha T, Sabiha K, Rukhsana K, Azam Z. Effect of Cinnamon extract on blood glucose level and lipid profile in Alloxan induced diabetic rats. Pak J Physiol 2011; 7: 1316.
22. El desoky GE, Aboul soud M, Al numair KS. Anti diabetic and hyperlipidemic effects of Ceylon cinnamon (Cinnamomum verum) in alloxan diabetic rats. J Medicin Plant Res 2012; $6: 1685$ 1691.

23. Gullapalli HS, Avinash P, Tekade MD, Namrata H. Effects of consumption of cinnamon on blood glucose and lipid profile of the patient of type 2 diabetes. Scholars J. Appl Med Sci 2013; 1:2832.

24. Khan A, Safdar M. Role of diet, nutrients, spices and natural products in Diabetes Mellitus. Pak $J$ Nutr.

\section{Don't make a permanent decision for you temporary emotion.}

